\title{
Prevalence and Associations of Cataract in a Rural Chinese Adult \\ Population: The Handan Eye Study
}

Running head: Prevalence of cataract in rural China

Xin Rong Duan MD, PhD, ${ }^{1}$ Yuan Bo Liang MD, PhD, ${ }^{1,2}$ Ning Li Wang MD, PhD, ${ }^{1}$ Tien Yin Wong FRCSE, PhD, ${ }^{3,4,5}$ Lan Ping Sun $M D,{ }^{2}$ Xiao Hui Yang, MD, PhD, ${ }^{1,6}$ Qiu Shan Tao MD, PhD ${ }^{7}$, Rui Zhi Yuan, ${ }^{2}$ David S Friedman MD, PhD, 8,9

${ }^{1}$ Beijing Tongren Eye Center, Beijing Tongren Hospital, Capital Medical University, Beijing Ophthalmology \& Visual Sciences Key Lab, Beijing, China; ${ }^{2}$ Handan Eye Hospital, Hebei Province, China;

${ }^{3}$ Singapore Eye Research Institute, Singapore; Singapore National Eye Centre, Singapore;

${ }^{4}$ Department of Ophthalmology, Yong Loo Lin School of Medicine, National University of Singapore, Singapore;

${ }^{5}$ Centre for Eye Research Australia, University of Melbourne, Australia;

${ }^{6}$ Beijing Institute of Ophthalmology, Beijing Tongren Hospital, Capital Medical University, Beijing, China;

${ }^{7}$ School of Public Health, Peking University, Beijing, China;

${ }^{8}$ Wilmer Eye Institute, Johns Hopkins University, United States;

${ }^{9}$ Department of International Health, Johns Hopkins Bloomberg School of Public Health, Baltimore, United States; 
Correspondence to:

Ning Li Wang, MD, PhD

Beijing Tongren Eye Center, Beijing Tongren Hospital, Capital Medical University, Beijing Ophthalmology \& Visual Sciences Key Lab, Beijing, China; No. 1 Dongjiao Min Xiang, Dongcheng District, Beijing, 100730, China Phone: +86-1058269919/ Fax: +86-1058269920/ Email: hes2006@yahoo.cn

Conflict of interest: No authors have any financial/conflicting interests to disclose.

Financial Support: This study was supported by the Program of Health Policy for blindness prevention from Ministry of Health the People's Republic of China, Partially funded by the Key Technologies R\&D Program.No.2006-10903 from Bureau of Science and Technology of Handan city, Hebei Province, China.

With additional supports from Beijing Tongren Hospital and key discipline fund of Bureau of Health, Handan city, Hebei Province, China.

The sponsor or funding organization had no role in the design or conduct of this research.

Word count: Abstract 315 Text 3227 (excluding title page, abstract, references \& tables) Tables 6 


\section{Abstract}

Background: Cataract remains the leading cause of blindness and visual impairment in the world and in China. However, data on the prevalence of cataract based on standardized lens grading protocols from mainland China are limited. This paper estimated the age- and gender-specific prevalence and risk factor for cataract

Methods: In a population-based Chinese sample, participants underwent a comprehensive ophthalmic examination including assessment of cortical, nuclear, posterior subcapsular (PSC) and mixed lens opacities from slit lamp grading using the Lens Opacities Classification System III.

Results: Of the 7,557 eligible subjects, 6,830 took part in the study $(90.4 \%$ response rate), and 6,544 participants (95.8\%, mean age $52.0 \pm 11.8$ years) had lens data for analyses. The prevalence of any cataract surgery in at least one eye was $0.8 \%$ (95\% confidence interval $[\mathrm{Cl}], 0.62,1.06)$, with similar rates between men and women. The overall prevalence of any cataract or cataract surgery was $20.8 \%(95 \% \mathrm{Cl}, 19.8,21.8)$, higher in women than in men after adjusting for age (23.6\% vs. $17.6 \%$; OR: $1.78 ; 95 \% \mathrm{Cl}: 1.54-2.07)$. When distinct lens opacity was categorized in each eye as cortical, nuclear, PSC or mixed, based on one randomly selected eye, cortical cataract was the most common distinct subtype (12.3\%), followed by mixed (3.2\%), nuclear (1.7\%), and PSC $(0.2 \%)$ cataract. The prevalence of all lens opacities increased with age $(P<0.001)$. After excluding other causes for visual impairment, the 
proportion of people with best corrected visual acuity $<20 / 60$ was $21 \%$ among those with PSC and 12\% among those with mixed opacities in the better seeing eye. In multivariable logistic regression models, myopia was associated with all cataract types, while higher fasting plasma glucose and diabetes were only associated with PSC cataract.

Conclusions: Cataract affects $20 \%$ of the population aged 30 years and older living in rural China, with cortical cataract the most common subtype. Risk factors for cataract include myopia and diabetes.

Keywords: cataract, prevalence, risk factor, population-based

Financial Disclosure(s): The authors have no proprietary or commercial interest in any materials discussed in this article. 
Cataract is the most common cause of blindness in the world, with the majority of those affected in Asia. ${ }^{[1-3]}$ In China, cataract remains the leading cause of blindness and visual impairment despite sustained public health efforts to increase cataract surgery rates. ${ }^{[4,5]}$ Furthermore the prevalence of cataract is expected to further increase with the aging of China's population. ${ }^{[1]}$

While there have been epidemiological studies on the prevalence of cataract in China, previous data based on standardized grading protocols are limited. ${ }^{[6,7]}$ Furthermore, almost all research on cataract has been conducted in either urban cities or in economically well-developed regions of China, ${ }^{[6,8-10]}$ and information on the prevalence of cataract among rural Chinese living in economically underdeveloped regions, who represent $60 \%$ (or 800 million) of the total Chinese population, is scarce.

The purpose of this report is therefore to describe in a rural Chinese population, the prevalence of and associated factors for lens opacity, measured and defined based on slit lamp examination using the Lens Opacities Classification System III (LOCS III).

\section{METHODS}

\section{Study Population}

The Handan Eye Study (HES) was designed to provide population-based prevalence estimates of eye disorders in rural adult Chinese people. Yongnian County, Handan, located in the south part of Hebei province (about 500 
kilometers south of Beijing) has demographic characteristics similar to other rural Chinese locations according to the 2000 China National Census. ${ }^{[12,13]}$ Residents of Yongnian County aged 30+ years were randomly selected using a clustered sampling technique with probabilities proportionate to the size of population in each cluster. Of the 458 villages in the Yongnian County, 13 were randomly selected to achieve a target sample size of 5,105 . The sampling frame was a list of persons living in the town obtained from the Household Resident Register Record Office of the local police stations. All residents aged $50+$ years in the selected 13 villages were invited to participate. In addition, in order to study individuals aged 30-49 years, we randomly selected six out of the 13 villages with probabilities proportionate to size where all residents aged 30-49 years were also invited.

A total of 8,653 individuals were selected and their permanent residency in the villages was confirmed in a door-to-door census. A person was considered ineligible if he had moved out of the village, had not lived there in the past six months, was deceased or was terminally ill with a life expectancy estimated to be less than 3 months. Of 8,653 individuals, 7557 (87.3\%) were considered eligible. The study protocol was approved and monitored by Beijing Tongren Hospital Ethical Committee and written informed consent was obtained from all participants at the time of the examination. For those who were illiterate, we read the consent form to them and asked them to mark the consent form with an inked forefinger. All study procedures adhered to the principles outlined in 
the Declaration of Helsinki for research involving human subjects. Details of the study design, sampling plan, and baseline data are reported elsewhere. ${ }^{[13,}$

14] The study was conducted from October 2006 to October 2007.

\section{Lens Examination Protocol}

The grading of lens opacity was performed by two senior ophthalmologists (XRD graded $70 \%$ and RZY), who were trained and certified according to a written standardized protocol, using slit lamp-based LOCS III. ${ }^{[15-18]}$ Participants were examined at a slit lamp after maximum dilation of pupils. The presence and severity of lens opacities was compared to LOCS III standard transparency which was next to the slit lamp and visible to the examining physician. Decimal grades were documented separately for cortical opacities (C; ranging from 0.1 to 5.9 , using 5 standards), nuclear opalescence (NO; ranging from 0.1 to 6.9 , using 6 standards), nuclear color (NC; ranging from 0.1 to 6.9 ), and posterior subcapsular opacities (P; ranging from 0.1 to 5.9 , using 5 standards). If grading was not possible, the reasons for not grading any regions in one or both eyes were also recorded.

\section{Definition of Lens Opacities}

Cataract was defined based on the LOCS III grade in four major characteristics: $\mathrm{C}, \mathrm{NO}, \mathrm{NC}$, and $\mathrm{P},{ }^{[15-18]}$ following similar criteria published by other groups using the LOCS III. ${ }^{[16,19,20]}$

1. Any cataract in a person: This definition was used to calculate person-based rates. Any cortical cataract as $C \geq 2$, any nuclear cataract 
was defined as $\mathrm{NO}$ or $\mathrm{NC} \geq 4$, and any posterior subcapsular cataract (PSC) as $\mathrm{P} \geq 2$ in either eye. If a person had unilateral cataract surgery or ungradable lens, the LOCS III score of the fellow eye was used. Any cataract or cataract surgery was defined as the presence, in at least one eye, of any cataract (cortical, nuclear, or PSC cataract meeting the criteria above) or a history of previous cataract surgery (pseudophakia or aphakia).

2. Distinct type of cataract in an eye: This definition included the presence of a distinct type of cataract in one eye, resulting in four mutually exclusive categories: cortical only, nuclear only, PSC only, and mixed cataract (more than one type in that eye). Prevalence of distinct types of lens opacities was based on eyes with gradable LOCS III findings in all regions (i.e., cortical, nuclear, and posterior subcapsular regions).

The reproducibility of LOCS III grading between 2 examiners was evaluated at the beginning and during the conduct of the study. The intra-grader consistency of one of the examiners (XRD) was also evaluated during the conduct of the study. The assessment consisted of performing an independent replicate grading on 30 participants aged $50+$ years.

\section{Examinations and Definitions of Other Variables}

A detailed interview was conducted asking ocular and medical histories and assessing various risk factors. Socioeconomic status including job, income, level of education of each participant was obtained from questionnaire. ${ }^{[13]}$ 
Visual acuity (VA) for each participant was measured using a log of the minimal angle of resolution (LogMAR) chart at a distance of 4 meters. Automated refraction was performed (Auto Refractometer KR 8800, Topcon Corp., Japan), followed by subjective refraction performed by trained optometrists on subjects with vision worse than $1.0(<20 / 20)$ in either eye (best corrected VA [BCVA]).

Blood pressure, height, weight, and Perkins applanation intraocular pressure were measured. Fasting plasma glucose, serum cholesterol, high density lipoprotein cholesterol (HDL), low density lipoprotein cholesterol (LDL) and triglyceride were tested in $83.7 \%$ participants.

Diabetes mellitus was diagnosed from a self-reported history of medication use and/or fasting plasma glucose greater than or equal to $7.0 \mathrm{mmol} / \mathrm{L}$. Hypertension was defined as having a history of hypertension on medication or elevated blood pressure when measured during the examination (diastolic blood pressure greater than or equal to $90 \mathrm{mmHg}$ or systolic blood pressure greater than or equal to $140 \mathrm{mmHg}$ ).

Refractive error was defined by spherical equivalent (SE, sum of spherical power and half of the cylinder power, in diopters). Emmetropia was defined as a SE between $-0.50 \mathrm{D}$ to $+0.50 \mathrm{D}$, hyperopia as a SE greater than $+0.50 \mathrm{D}$, myopia as a SE less than -0.50 D. ${ }^{[21]}$ Visual impairment was defined as a BCVA of $20 / 60$ or worse in an eye.

\section{Data Handling and Statistical Analyses}

Statistical Analysis System (SAS Institute Inc, Cary, NC, version 9.1.3) was 
used for tabulations and statistical analyses. Reproducibility of lens assessment was measured by intraclass correlation coefficient (ICC). Frequency distributions were used to determine the gender- and age-specific prevalence for each opacity type (all lens changes, any lens opacity, and single and mixed opacities). Chi-square analyses were used to determine the association of age- and gender-specific groups (by decade) and opacity type. All analyses were conducted at the 0.05 significance level. Multiple logistic regression was used to investigate the associations of the binary dependent variable 'presence vs absence of cataract' with continuous (e.g., age and biochemical parameters) and dichotomous variables (e.g., hypertension, diabetes, smoking and other indices of systemic disease status). Odds ratios $(\mathrm{OR})$ and $95 \%$ confidence intervals $(\mathrm{Cl})$ are reported.

\section{RESULTS}

Reproducibility analyses showed good inter-grader agreement for all opacity types. At the beginning of the study, ICC for cortical opacities was 0.98 $(95 \% \mathrm{Cl}=0.95-0.99) ; 0.97(0.93-0.99)$ for NO, $0.97(0.93-0.99)$ for NC and 1.00 (1.00-1.00) for PSC; and during the study, respective ICCs were 0.99 (0.97-0.99), 0.99 (0.98-1.00), 0.97 (0.94-0.99) and 1.00 (1.00-1.00). The respective intra-grader consistency of one examiner (XRD) was: 0.99 (0.97-0.99) for cortical opacities; 0.99 (0.98-0.99) for NO, 0.99 (0.97-0.99) for NC, and 0.99 (0.98-1.00) for PSC. 
Of the 7,557 eligible subjects, 6,830 took part in the study ( $90.4 \%$ response rate). Of the 6,830 participants, data on the lens were available for 6,544 subjects $(95.8 \%, 13,008$ eyes). The mean age of these participants was $52.0 \pm$ 11.8 years and $3516(53.7 \%)$ were women. Compared with those who were excluded, included persons were significantly younger, had higher serum HDL cholesterol and were more often illiterate. Both groups did not vary significantly in gender, spherical equivalent and other parameters (Table a). For 6,464 subjects, lens data were available from both eyes, while for the remaining 80 subjects, lens data were available from only one eye. Of the 652 eyes excluded from this analysis, 264 eyes (153 participants) did not undergo pupil dilation because of narrow angles or a diagnosis of angle-closure glaucoma and 388 eyes (215 participants) declined a slit-lamp examination or had missing lens data.

\section{Cataract Surgery}

Of the 6,544 subjects in this study, $55(0.8 \% ; 95 \% \mathrm{Cl}: 0.62-1.06 ; 71$ of $13,008$ eyes, $0.55 \% ; 95 \% \mathrm{Cl}: 0.42-0.67)$ had previous cataract operations, with similar rates $(P=0.22)$ between men $(1.0 \% ; 95 \% \mathrm{Cl}: 0.64-1.34)$ and women (0.7\%; 95\% Cl: 0.43-0.99; OR: 0.72; 95\% Cl: 0.42-1.23). Rates of cataract surgery in at least one eye increased significantly with age $(P$ for trend $<0.001)$. In the 5350 subjects aged $40+$ years, rate of cataract surgery in at least one eye was $0.9 \%(95 \% \mathrm{Cl}: 0.63-1.13)$.

\section{Prevalence and Characteristics of Cataracts}


After excluding those with cataract surgery in both eyes $(n=20), 6524$ persons had lens data on at least one eye for the analysis of lens opacity (6482 right eyes and 6486 left eyes). Overall, the prevalence of any lens change in the population was $20.8 \%(95 \% \mathrm{Cl}$ : $19.83-21.80$, Table b). In participants aged $40+$ years, the prevalence of any cataract or cataract surgery was $24.8 \%$ (95\% Cl: $23.66-25.98)$. The prevalence of any cataract or cataract surgery increased from $4.4 \%$ in those 40 to 49 years of age to $78.7 \%$ in those 70 years of age and older ( $\mathrm{P}$ for trend $<0.001)$. After adjusting for age, women were more likely to have lens changes than men (23.6\% vs. $17.6 \%$; OR: 1.78 ; 95\% Cl: 1.54-2.07).

The most common distinct type of cataract was cortical only, followed by mixed, nuclear only, and PSC only in one randomly selected eye of each subject (Table c). The prevalence of cortical only, nuclear only and mixed cataract was strongly associated with increasing age ( $P$ for trend $<0.001)$. After adjusting for age, no significant gender differences were found in the prevalence of nuclear only (1.6\% vs. $1.7 \%$; OR=0.9; $95 \% \mathrm{Cl}: 0.6-1.3)$ or PSC only cataract $(0.2 \%$ vs. $0.2 \% ; \mathrm{OR}=1.0 ; 95 \% \mathrm{Cl}: 0.4-2.8)$. However, women were more likely to have cortical only $(14.5 \%$ vs. $9.6 \%$; OR=1.7; $95 \% \mathrm{Cl}$ : 1.5-2.1) and mixed cataract (4.0\% vs. $2.3 \%$; OR=2.0; $95 \% \mathrm{Cl}: 1.5-2.8)$ than men.

\section{Prevalence of Visual Impairment and Cataracts}

The presence of visual impairment (BCVA of 20/60 or worse, according to 
the WHO criteria) was more common among individuals with PSC only and mixed opacities after excluding cases whose visual impairment was caused by other reasons (e.g., glaucoma, diabetic retinopathy, age related macular degeneration, myopic retinopathy). About $21 \%$ of those with PSC only and $12 \%$ of those with mixed opacities were visually impaired in the better-seeing eye. Visual impairment in the worse-seeing eye was $26 \%$ and $24 \%$ respectively in those with PSC only and mixed opacities.

\section{Risk Factor Associations with Cataracts}

Based on logistic regression models, after controlling for other factors, myopia was associated with an increased risk for all types of cataracts, whereas hyperopia was inversely associated with PSC only (Table d). Higher fasting plasma glucose and presence of diabetes were associated with PSC only cataracts (OR: $1.25,95 \% \mathrm{Cl}: 1.05-1.49 ;$ per mmol/L increase in glucose and OR: $5.03,95 \% \mathrm{Cl}: 1.25-20.25$ for presence of diabetes, respectively). Higher serum cholesterol was associated with nuclear opacities, whereas HDL and LDL cholesterol were inversely associated with nuclear opacities. None of the other previously suggested risk factors including body mass index (BMI), smoking and drinking habits (past and current smoking or drinking vs. never smoking or drinking), hypertension (history or examination), time spent outdoors, and level of income and education were significantly associated with any cataract or cataract type in our study (OR: $0.00-2.17$, all $P>0.05$, data not shown). 


\section{DISCUSSION}

In this large rural Chinese population aged 30 years and older, we report an overall prevalence rate of $20.8 \%$ for any cataract or cataract surgery. The prevalence increased to $24.7 \%$ among participants aged 40 years and older, and to $37.7 \%$ among those 50 years and older, after age standardization to the year 2000 China national census.

Direct comparison with other studies is limited by differences in the age distributions of the population examined, methodology of cataract assessment, and lack of universal 'epidemiological definitions' and 'cut-offs' for cataract. For example, the specific cut-off points to define cataract vary from study to study even when using the LOCS III. ${ }^{[16,23-25]}$ Nonetheless, in comparison with other studies of Chinese adults, our age-adjusted rate was similar to that seen in Yang County Eye Survey conducted in a rural area in Shanxi Province and Shihpai Eye Study in Taiwan ( $\geq 60$ years, $54.9 \%$ vs. $59.2 \%$ ) ${ }^{[26]}$ who used the same LOCS III system evaluation (Table e). The distribution of cataract types in our study was also similar to the Yang County Eye Survey in which the most common type was cortical only, but different from the Shihpai Eye Study which reported nuclear opacity as the most common type. This difference is likely due to differing definitions of nuclear cataract (the Shihpai Eye Study used NO or $\mathrm{NC} \geq 2$ to define nuclear cataract, whereas we used $\mathrm{NO}$ or $\mathrm{NC} \geq 4$, similar to the Tanjong Pagar Survey in Singapore and the Meiktila Eye Study in 
Myanmer). ${ }^{[16,25,26]}$ Compared with other studies in Asian countries which used the LOCS III, our age and gender standardized rate was lower than that observed in India, Singapore and Indonesia, ${ }^{[16,23,24]}$ but similar to that in another study in Myanmar ${ }^{[25]}$ (Table f).

Differences between whites and non-white populations in cataract type and prevalence have been elaborated previously. ${ }^{[27-29]}$ Many studies have reported that non-white persons are at increased risk for cortical cataract. ${ }^{[28]}$ For example, the Barbados Eye Study ${ }^{[27]}$ reported significant difference in types of lens opacities with a higher prevalence of any cataract and higher prevalence of cortical opacities in blacks compared to whites. Possible explanations for the type and prevalence difference of cataract have been attributed to genetic background or a higher exposure to cataract risk factors including diabetes and increased ultraviolet light exposure, but the exact underlying reasons, if it indeed exists, remain unclear and further investigations are warranted. ${ }^{[10,27,28]}$ Although cataract remains the leading cause of blindness, the surgical rate in China is low. In our study, only $1.4 \%$ of subjects over 50 years of age had previous cataract surgery. This rate was similar to that seen in the Shunyi District Eye Study ${ }^{[8]}$ conducted in the economically well developed suburb of Beijing in 1996 and the Shanxi Eye Survey conducted in a rural area of Shanxi Province in 2003 (Table e), and was similar to the result of a nine-province survey in rural China. ${ }^{[31]}$ Importantly, the cataract surgery rate in China is lower than that seen in most other Asian countries, such as Singapore, 
India, and Myanmar ${ }^{[16,23,25,32]}$ after age and gender standardization to the year 2000 world population ${ }^{[33]}$ (Table f). This may reflect the lack of knowledge about cataract and concerns about the quality of healthcare services and cataract surgery in rural China. ${ }^{[34]}$ These findings suggest that increased efforts to inform rural populations that cataract can be treated surgically, and improved training in surgery and postoperative management are needed to increase cataract surgical rates in rural China.

Consistent with other studies, we found that both unilateral and bilateral visual impairment were frequently associated with lens opacities, ${ }^{[27,35]}$ particularly for PSC cataract. We confirmed that cataract was the most common cause of both blindness (41.9\%) and low vision (48.2\%) in our study. ${ }^{[5]}$

With regards to risk factors, age is strongly related to prevalence of cataracts. ${ }^{[16,25]}$ Also consistent with previous studies, women had a higher prevalence of cataracts and cortical cataracts than men. ${ }^{[23,26]}$ While hormonal differences in older women have been postulated as a potential explanation for this gender difference, ${ }^{[36]}$ further etiologic studies are needed to clarify the relation between gender and cataract. Myopia was associated with any cataract and each cataract subtype, a finding similar to that from the Melbourne Visual Impairment Project Study ${ }^{[37]}$ The Tanjong Pagar Survey ${ }^{[38]}$ also found that nuclear and PSC cataract was associated with myopia, but not with axial length, suggesting that associations of myopia with cataract is likely 
related to the 'myopic shift' with age. ${ }^{[38,39]}$ The finding between higher fasting plasma glucose, diabetes and PSC cataracts are similar to several population-based and clinical-based studies. ${ }^{[17,40,41]}$ In contrast, a possible relationship between serum cholesterol and nuclear opacities needs to be verified since conflicting results have been reported in previous studies. ${ }^{[6,42]}$ We found no association between cataract and BMI, cigarette smoking and other previously reported risk factors. ${ }^{[17,24,26,37,43,44]}$ The failure to identify these associations could be due to different methodology, less precise measurement of some variables (e.g., assessment of hours outside as an indirect proxy to ultraviolet light exposure), less variation in the variables being studied (most were farmers, and spent a lot of time outdoors and most were smokers), or a spurious association being identified in the original studies.

Strengths of our study include its large sample size with high response rate in a population-based sample, and the use of standardized protocols when grading lens opacification. There are a number of limitations of this study. First, no lens photographs were taken. However, photographic documentation of cortical and nuclear opacities has been shown to correlate well with clinical grading at the slit lamp ${ }^{[35,45]}$ and lens grading was performed strictly adhering to the methodology specified in the LOCS III protocol with standard lens transparency and certification of graders. Second, the exclusion of small numbers of participants who did not undergo pupil dilation because of narrow angles or a diagnosis of angle-closure glaucoma could have resulted in a slight 
underestimate of the true cataract prevalence since these people are more likely to have cataract.

In conclusion, we report the prevalence of cataract in a population-based sample of subjects across a wide age range living in rural areas of China, using standardized LOCS III grading. We confirm that cataract is common and is a major cause of blindness and low vision in rural China. Key risk factors for cataract, including myopia and diabetes, are similar reported in our Chinese population. Further strengthening public health interventions in China are needed to tackle this major problem with an aging population. 


\section{References}

1. Thylefors B, Negrel AD, Pararajasegaram R, Dadzie KY (1995) Global data on blindness. Bull World Health Organ 73: 115-121

2. Resnikoff S, Pascolini D, Etya'ale D, Kocur I, Pararajasegaram R, Pokharel GP, Mariotti SP (2004) Global data on visual impairment in the year 2002. Bull World Health Organ 82: 844-851

3. Casson RJ, Newland HS, Muecke J, McGovern S, Durkin S, Sullivan T, Oo TZ, Aung TH, Shein WK, Selva D, Aung T (2007) Prevalence and causes of visual impairment in rural myanmar: the Meiktila Eye Study. Ophthalmology 114: 2302-2308

4. Xu L, Wang Y, Li Y, Cui T, Li J, Jonas JB (2006) Causes of blindness and visual impairment in urban and rural areas in Beijing: the Beijing Eye Study. Ophthalmology 113: 1134 e1131-1111

5. Liang YB, Friedman DS, Wong TY, Zhan SY, Sun LP, Wang JJ, Duan XR, Yang XH, Wang FH, Zhou Q, Wang NL (2008) Prevalence and causes of low vision and blindness in a rural chinese adult population: the Handan Eye Study. Ophthalmology 115: 1965-1972

6. Xu L, Cui T, Zhang S, Sun B, Zheng Y, Hu A, Li J, Ma K, Jonas JB (2006) Prevalence and risk factors of lens opacities in urban and rural Chinese in Beijing. Ophthalmology 113: 747-755

7. Quan YL YJ, RenBC (2006) Epidemic survey for cataract in Yang County, Shaanxi Province. Int J Ophthalmol 6: 1464-1467 
8. Zhao J, Sui R, Jia L (2001) Prevalence of cataract and surgical coverage among adults aged 50 or above in Shunyi District of Beijing, China. Zhonghua Yan Ke Za Zhi (Chin) 37: 3-8

9. Xu J, He M, Wu K, Li S (1999) The prevalence of cataract in Doumen County, Guangdong Province. Zhonghua Yan Ke Za Zhi (Chin) 35: $465-467$

10. Hu TS, Zhen Q, Sperduto RD, Zhao JL, Milton RC, Nakajima A (1989) Age-related cataract in the Tibet Eye Study. Arch Ophthalmol 107: $666-669$

11. China (2009) National Bureau of Statistics People's Republic of China. Major Figures of the 2000 population census. Available at:

http://www.cpirc.org.cn/en/e5cendata1.htm. Accessed July 15, 2009.

12. China (2007) China Population \& Development Research Center. The annual report of Chinese citizen income 2006. Available at:http://www.cpirc.org.cn/tijs/tjsj cy detail.asp?id=7938. Accessed: March 2, 2007.

13. Liang YB, Friedman DS, Wong TY, Wang FH, Duan XR, Yang XH, Zhou Q, Tao Q, Zhan SY, Sun LP, Wang NL (2009) Rationale, design, methodology, and baseline data of a population-based study in rural China: the Handan Eye Study. Ophthalmic Epidemiol 16: 115-127

14. Duan XR, Liang YB, Friedman DS, Sun LP, Wei WB, Wang JJ, Wang GL, Liu W, Tao QS, Wang NL, Wong TY (2009) Prevalence and 
associations of epiretinal membranes in a rural Chinese adult population: the Handan Eye Study. Invest Ophthalmol Vis Sci 50: 2018-2023

15. Chylack LT, Jr., Wolfe JK, Singer DM, Leske MC, Bullimore MA, Bailey IL, Friend J, McCarthy D, Wu SY (1993) The Lens Opacities Classification System III. The Longitudinal Study of Cataract Study Group. Arch Ophthalmol 111: 831-836

16. Seah SK, Wong TY, Foster PJ, Ng TP, Johnson GJ (2002) Prevalence of lens opacity in Chinese residents of Singapore: the tanjong pagar survey. Ophthalmology 109: 2058-2064

17. Foster PJ, Wong TY, Machin D, Johnson GJ, Seah SK (2003) Risk factors for nuclear, cortical and posterior subcapsular cataracts in the Chinese population of Singapore: the Tanjong Pagar Survey. Br J Ophthalmol 87: 1112-1120

18. Karbassi M, Khu PM, Singer DM, Chylack LT, Jr. (1993) Evaluation of lens opacities classification system III applied at the slitlamp. Optom Vis Sci 70: 923-928

19. Leske MC, Chylack LT, Jr., He Q, Wu SY, Schoenfeld E, Friend J, Wolfe $J$ (1997) Incidence and progression of cortical and posterior subcapsular opacities: the Longitudinal Study of Cataract. The LSC Group. Ophthalmology 104: 1987-1993

20. Evans JR, Rauf A, Aihie Sayer A, Wormald RP, Cooper C (1998) 
Age-related nuclear lens opacities are associated with reduced growth before 1 year of age. Invest Ophthalmol Vis Sci 39: 1740-1744

21. Wang Q, Klein BE, Klein R, Moss SE (1994) Refractive status in the Beaver Dam Eye Study. Invest Ophthalmol Vis Sci 35: 4344-4347

22. China (2009) National Bureau of Statistics of China. Available at: http://www.stats.gov.cn/tjsj/ndsj/renkoupucha/2000pucha/html//0102.ht m. Accessed August 2, 2009.

23. Nirmalan PK, Krishnadas R, Ramakrishnan R, Thulasiraj RD, Katz J, Tielsch JM, Robin AL (2003) Lens opacities in a rural population of southern India: the Aravind Comprehensive Eye Study. Invest Ophthalmol Vis Sci 44: 4639-4643

24. Husain R, Tong L, Fong A, Cheng JF, How A, Chua WH, Lee L, Gazzard G, Tan DT, Koh D, Saw SM (2005) Prevalence of cataract in rural Indonesia. Ophthalmology 112: 1255-1262

25. Athanasiov PA, Casson RJ, Sullivan T, Newland HS, Shein WK, Muecke JS, Selva D, Aung T (2008) Cataract in rural Myanmar: prevalence and risk factors from the Meiktila Eye Study. $\mathrm{Br} \mathrm{J}$ Ophthalmol 92: 1169-1174

26. Tsai SY, Hsu WM, Cheng CY, Liu JH, Chou P (2003) Epidemiologic study of age-related cataracts among an elderly Chinese population in Shih-Pai, Taiwan. Ophthalmology 110: 1089-1095

27. Leske MC, Connell AM, Wu SY, Hyman L, Schachat A (1997) 
Prevalence of lens opacities in the Barbados Eye Study. Arch Ophthalmol 115: 105-111

28. West SK, Munoz B, Schein OD, Duncan DD, Rubin GS (1998) Racial differences in lens opacities: the Salisbury Eye Evaluation (SEE) project. Am J Epidemiol 148: 1033-1039

29. Sasaki K, Sasaki H, Jonasson F, Kojima M, Cheng HM (2004) Racial differences of lens transparency properties with aging and prevalence of age-related cataract applying a WHO classification system. Ophthalmic Res 36: 332-340

30. Peng YS ZA, Chen L, He Y, Ren BC (2007) Prevalence of age related cataract and blindness in rural areas of Shaanxi province. Int $\mathrm{J}$ Ophthalmol 7: 220-223

31. Zhao J, Ellwein LB, Cui H, Ge J, Guan H, Lv J, Ma X, Yin J, Yin ZQ, Yuan Y, Liu H (2010) Prevalence and outcomes of cataract surgery in rural china the china nine-province survey. Ophthalmology 117 : $2120-2128$

32. Lavanya R, Wong TY, Aung T, Tan DT, Saw SM, Tay WT, Wang JJ (2009) Prevalence of cataract surgery and post-surgical visual outcomes in an urban Asian population: the Singapore Malay Eye Study. Br J Ophthalmol 93: 299-304

33. Nations U (2008) United Nations, World population prospects: The 2006 Revision Population Database. Available at: 
http://esa.un.org/unpp/p2k0data.asp. Accessed May 30, 2008.

34. Yin Q, Hu A, Liang Y, Zhang J, He M, Lam DS, Ge J, Wang N, Friedman DS, Zhao J, Congdon N (2009) A two-site, population-based study of barriers to cataract surgery in rural china. Invest Ophthalmol Vis Sci 50: 1069-1075

35. Varma R, Torres M (2004) Prevalence of lens opacities in Latinos: the Los Angeles Latino Eye Study. Ophthalmology 111: 1449-1456

36. Cumming RG, Mitchell P (1997) Hormone replacement therapy, reproductive factors, and cataract. The Blue Mountains Eye Study. Am J Epidemiol 145: 242-249

37. McCarty CA, Mukesh BN, Fu CL, Taylor HR (1999) The epidemiology of cataract in Australia. Am J Ophthalmol 128: 446-465

38. Wong TY, Foster PJ, Johnson GJ, Seah SK (2003) Refractive errors, axial ocular dimensions, and age-related cataracts: the Tanjong Pagar survey. Invest Ophthalmol Vis Sci 44: 1479-1485

39. Shufelt C, Fraser-Bell S, Ying-Lai M, Torres M, Varma R (2005) Refractive error, ocular biometry, and lens opalescence in an adult population: the Los Angeles Latino Eye Study. Invest Ophthalmol Vis Sci 46: $4450-4460$

40. Delcourt C, Cristol JP, Tessier F, Leger CL, Michel F, Papoz L (2000) Risk factors for cortical, nuclear, and posterior subcapsular cataracts: the POLA study. Pathologies Oculaires Liees a l'Age. Am J Epidemiol 
151: $497-504$

41. Rowe NG, Mitchell PG, Cumming RG, Wans JJ (2000) Diabetes, fasting blood glucose and age-related cataract: the Blue Mountains Eye Study. Ophthalmic Epidemiol 7: 103-114

42. Hiller R, Sperduto RD, Reed GF, D'Agostino RB, Wilson PW (2003) Serum lipids and age-related lens opacities: a longitudinal investigation: the Framingham Studies. Ophthalmology 110: 578-583

43. Wu R, Wang JJ, Mitchell P, Lamoureux EL, Zheng Y, Rochtchina E, Tan AG, Wong TY (2010) Smoking, socioeconomic factors, and age-related cataract: The Singapore Malay Eye study. Arch Ophthalmol 128: 1029-1035

44. Delcourt C, Carriere I, Delage M, Descomps B, Cristol JP, Papoz L (2003) Associations of cataract with antioxidant enzymes and other risk factors: the French Age-Related Eye Diseases (POLA) Prospective Study. Ophthalmology 110: 2318-2326

45. Adamsons I, Taylor KI, Enger C, Taylor HR (1991) A new method for documenting lens opacities. Am J Ophthalmol 111: 65-70

46. Klein BE, Klein R, Linton KL (1992) Prevalence of age-related lens opacities in a population. The Beaver Dam Eye Study. Ophthalmology 99: 546-552

47. Mitchell P, Cumming RG, Attebo K, Panchapakesan J (1997) Prevalence of cataract in Australia: the Blue Mountains eye study. 
Ophthalmology 104: 581-588 
TABLE a. Characteristics of Participants Included and Excluded from the Analysis

\begin{tabular}{|c|c|c|c|}
\hline & $\begin{array}{l}\text { Included } \\
(\mathrm{n}=6544)\end{array}$ & $\begin{array}{l}\text { Excluded } \\
(\mathrm{n}=286)\end{array}$ & $\mathbf{P}$ \\
\hline Gender (Female, \%) & 53.7 & 52.8 & 0.757 \\
\hline Age $(y$, Mean $\pm S D)$ & $52.0 \pm 11.8$ & $60.8 \pm 15.9$ & $<0.001^{* *}$ \\
\hline Spherical Equivalent (D, Mean $\pm S D$ ) & $-0.10 \pm 1.80$ & $-0.30 \pm 1.80$ & 0.370 \\
\hline Body Mass Index $\left(\mathrm{kg} / \mathrm{m}^{2}\right.$, Mean $\left.\pm \mathrm{SD}\right)$ & $24.50 \pm 3.75$ & $24.51 \pm 4.61$ & 0.975 \\
\hline Serum cholesterol $(\mathrm{mmol} / \mathrm{l}$, Mean $\pm \mathrm{SD})$ & $4.61 \pm 0.95$ & $4.61 \pm 1.08$ & 0.989 \\
\hline Serum triglyceride $(\mathrm{mmol} / \mathrm{l}$, Mean $\pm \mathrm{SD})$ & $1.51 \pm 1.05$ & $1.65 \pm 1.05$ & 0.155 \\
\hline Serum HDL cholesterol $(\mathrm{mmol} / \mathrm{l}$, Mean $\pm \mathrm{SD})$ & $1.28 \pm 0.29$ & $1.21 \pm 0.24$ & $0.009^{* *}$ \\
\hline Serum LDL cholesterol (mmol/l, Mean \pm SD) & $2.71 \pm 0.65$ & $2.73 \pm 0.72$ & 0.733 \\
\hline Diabetic Mellitus (\%) & 6.8 & 11.3 & 0.090 \\
\hline Hypertension (\%) & 47.6 & 51.5 & 0.318 \\
\hline Drinking (\%, past and current vs. never) & 18.6 & 18.8 & 0.980 \\
\hline Smoking (\%, past and current vs. never) & 27.4 & 31.5 & 0.209 \\
\hline Income $(\%,<3500 ¥ /$ year $)$ & 59.6 & 50.4 & 0.055 \\
\hline Level of Education & & & $0.009^{\star *}$ \\
\hline Illiteracy (\%) & 11.4 & 17.1 & \\
\hline Partial literacy (\%) & 54.2 & 54.9 & \\
\hline Primary school (\%) & 31.4 & 26.2 & \\
\hline Middle school or higher (\%) & 3.0 & 1.8 & \\
\hline${ }^{* *} p<0.01,{ }^{*} p<0.05$ & & & \\
\hline
\end{tabular}


TABLE b. Age- and Gender-specific Prevalence of Any Cataract in the Handan Eye Study

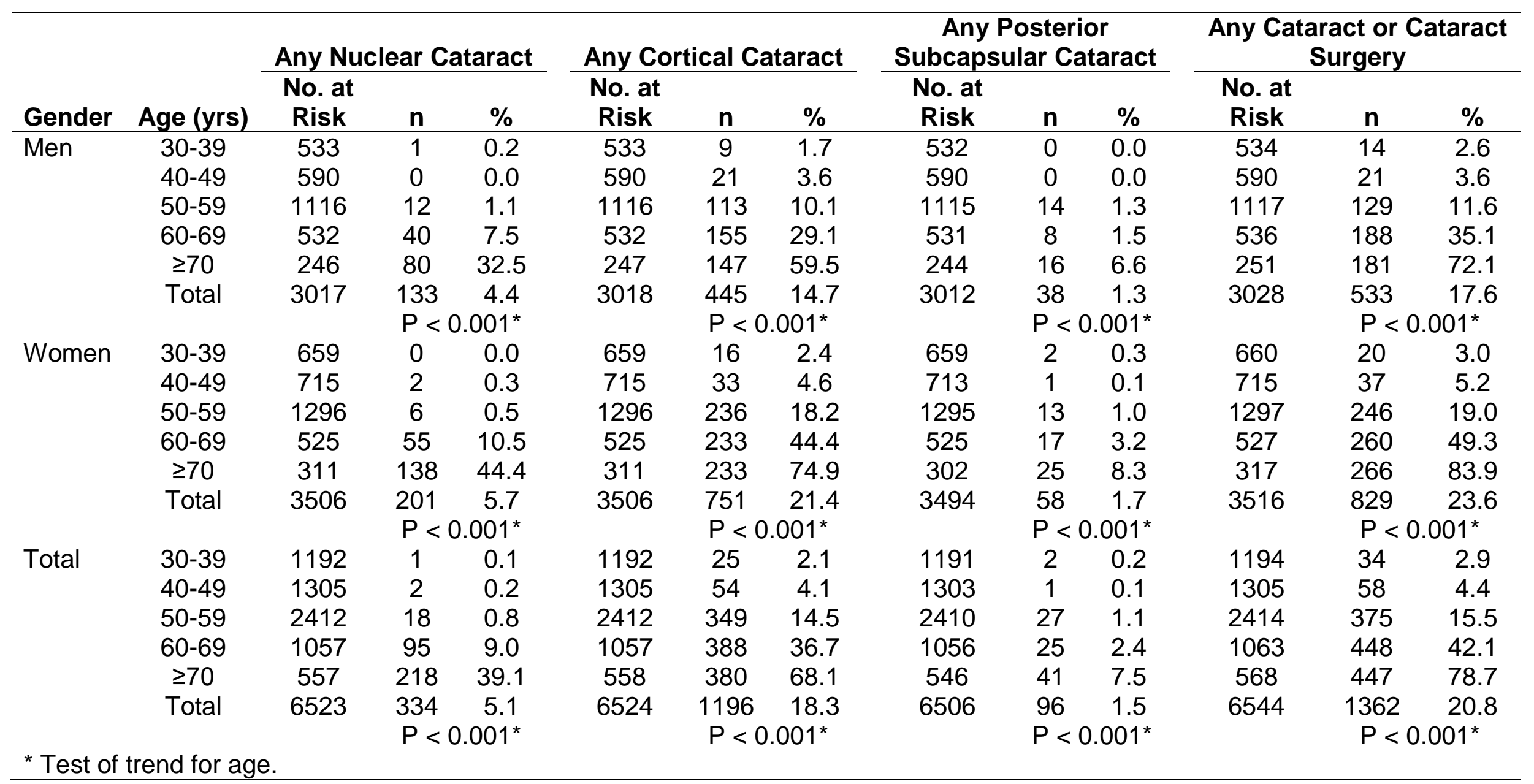


TABLE c. Age- and Gender-specific Prevalence of Distinct Types of Cataract in One Randomly Selected Eye of Each Subject in the Handan Eye Study

\begin{tabular}{|c|c|c|c|c|c|c|c|c|c|c|}
\hline \multirow[b]{2}{*}{ Gender } & \multirow[b]{2}{*}{ Age (yrs) } & \multirow{2}{*}{$\begin{array}{c}\text { No. at } \\
\text { Risk }\end{array}$} & \multicolumn{2}{|c|}{ Mixed } & \multicolumn{2}{|c|}{ Nuclear Only } & \multicolumn{2}{|c|}{ Cortical Only } & \multicolumn{2}{|c|}{$\begin{array}{c}\text { Posterior } \\
\text { Subcapsular } \\
\text { Only }\end{array}$} \\
\hline & & & $\mathbf{n}$ & $\%$ & $\mathbf{n}$ & $\%$ & $\mathbf{n}$ & $\%$ & $\mathbf{n}$ & $\%$ \\
\hline \multirow[t]{7}{*}{ Men } & $30-39$ & 531 & 0 & 0.0 & 0 & 0.0 & 6 & 1.1 & 0 & 0.0 \\
\hline & $40-49$ & 590 & 0 & 0.0 & 0 & 0.0 & 15 & 2.5 & 0 & 0.0 \\
\hline & $50-59$ & 1110 & 8 & 0.7 & 3 & 0.3 & 78 & 7.0 & 4 & 0.4 \\
\hline & $60-69$ & 522 & 14 & 2.7 & 23 & 4.4 & 110 & 21.1 & 3 & 0.6 \\
\hline & $\geq 70$ & 237 & 47 & 19.8 & 26 & 11.0 & 79 & 33.3 & 0 & 0.0 \\
\hline & Total & 2990 & 69 & 2.3 & 52 & 1.7 & 288 & 9.6 & 7 & 0.2 \\
\hline & & & \multicolumn{2}{|c|}{$P<0.001^{*}$} & \multicolumn{2}{|c|}{$P<0.001^{*}$} & \multicolumn{2}{|c|}{$P<0.001^{*}$} & \multicolumn{2}{|c|}{$P=0.140^{*}$} \\
\hline \multirow[t]{7}{*}{ Women } & $30-39$ & 657 & 0 & 0.0 & 0 & 0.0 & 15 & 2.3 & 1 & 0.2 \\
\hline & $40-49$ & 711 & 0 & 0.0 & 1 & 0.1 & 27 & 3.8 & 1 & 0.1 \\
\hline & $50-59$ & 1285 & 7 & 0.5 & 2 & 0.2 & 183 & 14.2 & 3 & 0.2 \\
\hline & $60-69$ & 513 & 33 & 6.4 & 23 & 4.5 & 170 & 33.1 & 2 & 0.4 \\
\hline & $\geq 70$ & 297 & 100 & 33.7 & 29 & 9.8 & 108 & 36.4 & 1 & 0.3 \\
\hline & Total & 3463 & 140 & 4.0 & 55 & 1.6 & 503 & 14.5 & 8 & 0.2 \\
\hline & & & \multicolumn{2}{|c|}{$P<0.001^{*}$} & \multicolumn{2}{|c|}{$P<0.001^{*}$} & \multicolumn{2}{|c|}{$P<0.001^{*}$} & \multicolumn{2}{|c|}{$P=0.348^{*}$} \\
\hline \multirow[t]{7}{*}{ Total } & $30-39$ & 1188 & 0 & 0.0 & 0 & 0.0 & 21 & 1.8 & 1 & 0.1 \\
\hline & $40-49$ & 1301 & 0 & 0.0 & 1 & 0.1 & 42 & 3.2 & 1 & 0.1 \\
\hline & $50-59$ & 2395 & 15 & 0.6 & 5 & 0.2 & 261 & 10.9 & 7 & 0.3 \\
\hline & $60-69$ & 1035 & 47 & 4.5 & 46 & 4.4 & 280 & 27.1 & 5 & 0.5 \\
\hline & $\geq 70$ & 534 & 147 & 27.5 & 55 & 10.3 & 187 & 35.0 & 1 & 0.2 \\
\hline & Total & 6453 & 209 & 3.2 & 107 & 1.7 & 791 & 12.3 & 15 & 0.2 \\
\hline & & & \multicolumn{2}{|c|}{$P<0.001^{*}$} & $\mathrm{P}$ & $1^{*}$ & \multicolumn{2}{|c|}{$P<0.001^{*}$} & \multicolumn{2}{|c|}{$P=0.091^{*}$} \\
\hline
\end{tabular}


TABLE d. Results of Multivariate Analysis of Risk Factors for Any Cataract and Specific Cataract Subtypes in the Handan Eye Study

\begin{tabular}{|c|c|c|c|c|}
\hline Characteristics & $\begin{array}{l}\text { Any Cataract or } \\
\text { Cataract Surgery } \\
(\mathrm{OR}, 95 \% \mathrm{Cl})\end{array}$ & $\begin{array}{l}\text { Nuclear Only } \\
\text { (OR, 95\% Cl) }\end{array}$ & $\begin{array}{l}\text { Cortical Only } \\
\text { (OR, 95\% Cl) }\end{array}$ & $\begin{array}{c}\text { Posterior Subcapsular } \\
\text { Only (OR, 95\% Cl) }\end{array}$ \\
\hline Myopia & $2.37(1.78,3.17)$ ** & $6.47(3.14,13.32)$ ** & $2.17(1.60,2.95)$ ** & $6.67(2.56,17.36) * *$ \\
\hline Hyperopia & $0.77(0.59,1.01)$ & $0.58(0.27,1.21)$ & $0.81(0.61,1.06)$ & $0.16(0.03,0.85)$ * \\
\hline Fasting Glucose (mmol/L) & $1.09(0.99,1.19)$ & $1.06(0.82,1.37)$ & $1.05(0.95,1.15)$ & $1.25(1.05,1.49)$ * \\
\hline $\begin{array}{l}\text { Serum HDL cholesterol } \\
(\mathrm{mmol} / \mathrm{l})\end{array}$ & $0.83(0.40,1.71)$ & $0.13(0.02,0.74)$ * & $0.91(0.43,1.90)$ & $6.78(0.56,82.69)$ \\
\hline $\begin{array}{l}\text { Serum LDL cholesterol } \\
(\mathrm{mmol} / \mathrm{l})\end{array}$ & $0.65(0.30,1.39)$ & $0.11(0.03,0.44) * *$ & $0.69(0.32,1.51)$ & $2.19(0.18,27.13)$ \\
\hline
\end{tabular}


TABLE e. Comparison of the age standardized prevalence of cataract in Handan Eye Study and other population-based eye studies in China using the year 2000 China national census.

\begin{tabular}{|c|c|c|c|c|c|c|c|c|c|c|}
\hline Study & Region & $\begin{array}{c}\text { Year } \\
\text { Conducted }\end{array}$ & $\begin{array}{c}\text { Urban/ } \\
\text { Rural }\end{array}$ & $\begin{array}{c}\text { Age } \\
\text { Range }\end{array}$ & $\begin{array}{c}\text { Population at } \\
\text { Risk }\end{array}$ & $\begin{array}{l}\text { Method of } \\
\text { Evaluation }\end{array}$ & $\begin{array}{c}\text { Prevalence } \\
(\%)\end{array}$ & $\begin{array}{c}\text { Rate of } \\
\text { Cataract } \\
\text { Surgery (\%) }\end{array}$ & $\begin{array}{l}\text { Age-Standardized } \\
\text { Rate }(\%, 95 \% \mathrm{Cl})\end{array}$ & $\begin{array}{l}\text { Age-Standardized } \\
\text { Cataract Surgery } \\
\text { Rate }(\%, 95 \% \mathrm{Cl})\end{array}$ \\
\hline $\begin{array}{l}\text { Tibet Eye Study } \\
\text { [10] }\end{array}$ & Tibet & 1987 & Suburb & $\geq 20$ & 2660 & $\begin{array}{c}\text { Slit-lamp evaluation } \\
\text { \& Visual Acuity < } \\
6 / 12\end{array}$ & 5.6 & Not available & $14.2(12.9-15.5)$ & Not available \\
\hline $\begin{array}{l}\text { Shunyi District } \\
\text { Eye Study }{ }^{[8]}\end{array}$ & Beijing & 1996 & Suburb & $\geq 50$ & 5084 & $\begin{array}{c}\text { Slit-lamp evaluation } \\
\text { \& Pinhole Visual } \\
\text { Acuity }<0.7\end{array}$ & 23.3 & 1.7 & $22.3(21.2-23.5)$ & $1.4(1.3-2.0)$ \\
\hline $\begin{array}{l}\text { Doumen } \\
\text { County Eye } \\
\text { Study }^{[9]}\end{array}$ & $\begin{array}{l}\text { Guangdong } \\
\text { Province }\end{array}$ & 1997 & Rural & $\geq 50$ & 5342 & $\begin{array}{c}\text { Slit-lamp evaluation } \\
\text { \& Pinhole Visual } \\
\text { Acuity }<0.7\end{array}$ & 20.9 & 2.0 & $14.1(13.1-15.0)$ & Not available \\
\hline $\begin{array}{l}\text { Shihpai Eye } \\
\text { Study }{ }^{[26]}\end{array}$ & Taiwan & $1999-2000$ & Community & $\geq 65$ & 1361 & $\begin{array}{c}\text { Slit-lamp evaluation } \\
\text { with } \\
\text { LOCS III system }\end{array}$ & 59.2 & 12.9 & Not available & Not available \\
\hline $\begin{array}{l}\text { Beijing Eye } \\
\text { Study }{ }^{[6]}\end{array}$ & Beijing & 2001 & $\begin{array}{l}\text { Urban and } \\
\text { rural }\end{array}$ & $\geq 40$ & 4378 & $\begin{array}{l}\text { Photographs of } \\
\text { lens using a } \\
\text { modification of the } \\
\text { Age-related Eye } \\
\text { Disease Study } \\
\text { (AREDS) }\end{array}$ & 53.1 & 1.3 & Not available & Not available \\
\hline $\begin{array}{l}\text { Shanxi Eye } \\
\text { Survey }^{[30]}\end{array}$ & $\begin{array}{l}\text { Shanxi } \\
\text { Province }\end{array}$ & 2003 & Rural & $\geq 50$ & 1762 & Slit-lamp evaluation & 37.2 & 1.1 & $39.5(37.2-41.8)$ & $1.3(0.7-1.8)$ \\
\hline $\begin{array}{l}\text { Yang County } \\
\text { Eye Survey }{ }^{[7]}\end{array}$ & $\begin{array}{c}\text { Shanxi } \\
\text { Province }\end{array}$ & 2006 & Rural & $\geq 50$ & 1536 & $\begin{array}{c}\text { Slit-lamp evaluation } \\
\text { with } \\
\text { LOCS III system }\end{array}$ & 29.4 & 0.5 & $33.7(31.4-36.1)$ & Not available \\
\hline
\end{tabular}




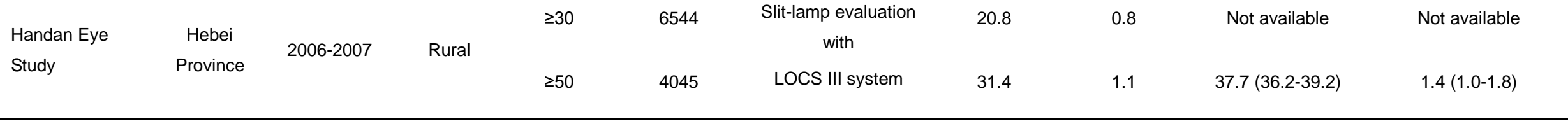


TABLE f. Comparison of the age and gender standardized prevalence of cataract in Handan Eye Study and other population-based eye studies using the year 2000 world population. ${ }^{[33]}$

\begin{tabular}{|c|c|c|c|c|c|c|c|c|c|c|}
\hline Study & Country & $\begin{array}{c}\text { Year } \\
\text { Conducted }\end{array}$ & Ethnicity & $\begin{array}{c}\text { Age } \\
\text { Range }\end{array}$ & $\begin{array}{l}\text { Population } \\
\text { at Risk }\end{array}$ & $\begin{array}{l}\text { Method of } \\
\text { Evaluation }\end{array}$ & $\begin{array}{c}\text { Prevalence } \\
(\%)\end{array}$ & $\begin{array}{c}\text { Rate of Cataract } \\
\text { Surgery (\%) }\end{array}$ & $\begin{array}{c}\text { Age \& Gender- } \\
\text { standardized } \\
\text { Rate }(\%, 95 \% \mathrm{Cl})\end{array}$ & $\begin{array}{c}\text { Age\& Gender } \\
\text {-standardized } \\
\text { Cataract } \\
\text { Surgery Rate } \\
(\%, 95 \% \mathrm{Cl})\end{array}$ \\
\hline $\begin{array}{l}\text { Beaver Dam } \\
\text { Eye Study }{ }^{[46]}\end{array}$ & $\begin{array}{l}\text { United States } \\
\text { of America }\end{array}$ & 1988-1990 & $\begin{array}{c}\text { non-Hispanic } \\
\text { white }\end{array}$ & $43-84$ & 4646 & $\begin{array}{l}\text { Photographic } \\
\text { evaluation with } \\
\text { standardized } \\
\text { system }\end{array}$ & 46.1 & 3.6 & Not available & Not available \\
\hline $\begin{array}{l}\text { Barbados Eye } \\
\text { Study }{ }^{[27]}\end{array}$ & Barbados & 1987-1992 & black most & $40-84$ & 4631 & $\begin{array}{c}\text { Slit-lamp } \\
\text { evaluation with } \\
\text { LOCS II system }\end{array}$ & 41.0 & 3.0 & Not available & Not available \\
\hline $\begin{array}{l}\text { Blue Mountains } \\
\text { Eye Study }{ }^{[47]}\end{array}$ & Australia & 1992-1994 & $\begin{array}{c}\text { non-Hispanic } \\
\text { white }\end{array}$ & $\geq 49$ & 3444 & $\begin{array}{l}\text { Photographic } \\
\text { evaluation with } \\
\text { standardized } \\
\text { system }\end{array}$ & 54.6 & 6.0 & Not available & Not available \\
\hline $\begin{array}{l}\text { Salisbury Eye } \\
\text { Evaluation } \\
\text { Study }^{[28]}\end{array}$ & $\begin{array}{l}\text { United States } \\
\text { of America }\end{array}$ & 1993-1995 & $\begin{array}{l}\text { Caucasians } \\
\text { African } \\
\text { Americans }\end{array}$ & $65-84$ & $\begin{array}{l}1772 \\
621\end{array}$ & $\begin{array}{l}\text { Photographic } \\
\text { evaluation with } \\
\text { standardized } \\
\text { system }\end{array}$ & 55.1 & 12.2 & $\begin{array}{l}\text { Not available } \\
\text { Not available }\end{array}$ & Not available \\
\hline $\begin{array}{l}\text { Aravind } \\
\text { Comprehensive } \\
\text { Eye Study }{ }^{[23]}\end{array}$ & India & $1995-1997$ & Indian & $\geq 40$ & 5150 & $\begin{array}{c}\text { Slit-lamp } \\
\text { evaluation with } \\
\text { LOCS III system }\end{array}$ & 47.5 & 9.4 & $48.5(47.1-49.8)$ & $10.5(9.6-11.3)$ \\
\hline $\begin{array}{l}\text { Tanjong } \\
\text { Pagar Survey }\end{array}$ & Singapore & 1997-1998 & Chinese & $40-81$ & 1206 & $\begin{array}{c}\text { Slit-lamp } \\
\text { evaluation with }\end{array}$ & 34.7 & 5.1 & 42.7 (39.9-45.5) & $7.3(5.9-8.8)$ \\
\hline
\end{tabular}


LOCS III system

\begin{tabular}{|c|c|c|c|c|c|c|c|c|c|c|}
\hline $\begin{array}{l}\text { Los Angeles } \\
\text { Latino Eye } \\
\text { Study }{ }^{[35]}\end{array}$ & $\begin{array}{c}\text { United States } \\
\text { of America }\end{array}$ & $2000-2003$ & Latinos & $\geq 40$ & 6090 & $\begin{array}{c}\text { Slit-lamp } \\
\text { evaluation with } \\
\text { LOCS II system }\end{array}$ & 19.5 & 3.9 & $20.8(19.8-21.8)$ & Not available \\
\hline \multirow{2}{*}{$\begin{array}{l}\text { A Study in Rural } \\
\text { Sumatra }^{[24]}\end{array}$} & \multirow[t]{2}{*}{ Indonesia } & \multirow[t]{2}{*}{2003} & \multirow[t]{2}{*}{ Malay } & $21-86$ & 914 & $\begin{array}{c}\text { Slit-lamp } \\
\text { evaluation with }\end{array}$ & 22.6 & 0.7 & Not available & Not available \\
\hline & & & & $\geq 40$ & 414 & LOCS III system & 44.9 & 1.4 & $40.8(36.0-45.5)$ & $1.2(0.2-2.3)$ \\
\hline $\begin{array}{l}\text { Meiktila Eye } \\
\text { Study }{ }^{[25]}\end{array}$ & Myanmar & 2005 & Burman & $\geq 40$ & 2044 & $\begin{array}{c}\text { Slit-lamp } \\
\text { evaluation with } \\
\text { LOCS III system }\end{array}$ & 40.4 & 3.3 & $33.5(31.5-35.6)$ & $1.9(1.3-2.5)$ \\
\hline \multirow{2}{*}{$\begin{array}{l}\text { Handan Eye } \\
\text { Study }\end{array}$} & \multirow[t]{2}{*}{ China } & \multirow[t]{2}{*}{$2006-2007$} & \multirow[t]{2}{*}{ Chinese } & $\geq 30$ & 6544 & $\begin{array}{c}\text { Slit-lamp } \\
\text { evaluation with }\end{array}$ & 20.8 & 0.8 & Not available & Not available \\
\hline & & & & $\geq 40$ & 5350 & LOCS III system & 24.8 & 0.9 & $25.7(24.6-26.9)$ & $1.0(0.7-1.2)$ \\
\hline
\end{tabular}

